ARTICLE

DOI: $10.1057 /$ s41599-018-0104-x

\title{
Socially mediated populism: the communicative strategies of political leaders on Facebook
}

\author{
Gianpietro Mazzoleni ${ }^{1} \&$ Roberta Bracciale ${ }^{2}$
}

\begin{abstract}
Populism has been defined in many different ways, mostly in regard to political ideology and political dynamics, but only in recent years in relation to communication variables. The aim of this paper is to contribute to the identification of a socially mediated type of populist communication profoundly affected by the specific nature of social media. It presents and discusses empirical evidence on Italy's populist and non-populist leaders that use Facebook regularly, and highlights the extent of the overflow of populist communication patterns and ideological features into mainstream political communication. Populist ideology fragments emerged in Italian leaders' Facebook posts, thus leading to two main conclusions: first, populism appears to be 'endemic' in the Italian online facebooksphere; second, political actors-even non-populist ones-do not disdain the adoption of typical populist rhetorics.
\end{abstract}

\footnotetext{
${ }^{1}$ Social and Political Sciences, University of Milan, Via Conservatorio, 7, 20122 Milano, Italy. ${ }^{2}$ Political Science, University of Pisa," Via Filippo Serafini, 3, 56126 Pisa, Italy. Correspondence and requests for materials should be addressed to G.M. (email: gianpietro.mazzoleni@unimi.it)

or to R.B. (email: roberta.bracciale@unipi.it)
} 


\section{Introduction}

W hile we were writing this paper, thousands of far-right demonstrators with faces covered took to the streets of Warsaw waving flags and burning red flares, chanting slogans like 'White Europe of brotherly nations,' 'Pure Poland, white Poland!' and 'Refugees get out!'. A banner read: 'Pray for an Islamic Holocaust' (The Guardian 12 November 2017). What was thought unthinkable at the turn of the Millennium has become the reality over recent years. To initiate the slide that led to the present state of affairs in Europe was Austria, which embarked the populist party Freiheitliche Partei Österreichs (FPÖ), led at the time by the charismatic leader Jörg Haider, in a national government coalition in 2000. There followed Sweden, Hungary, Finland, Norway, Poland, Czech Republic, and it has again been Austria to close the current cycle by striking a new deal between Österreichische Volkspartei with FPÖ. Where the populists are not in power or failed to acquire it by democratic means, they have achieved significant approval ratings in the past decade: Marine Le Pen's Front National, Geert Wilders' PVV, Matteo Salvini's Lega Nord, Beppe Grillo's 5 Star Movement, and Germany's AfD, to mention only the most known, reflecting the rise of sympathies for populist parties (see Fig. 1).

Other populist formations of varying political weight have intermittently arisen and also dissolved - not without having first provoked political turmoil-as was the case of Nigel Farage's Ukip, credited with the 'Brexit mayhem'.

As the scholarly literature has duly pointed out (Rooduijn, 2014; Taggart, 2004), populism is not always and everywhere synonymous with far-right, extremist, sovereignty-demanding movements. In Europe one sees left-wing parties such as Syriza and Podemos sharing themes and rhetorics (like anti-elitism) with the parties on the other side of the political/populist spectrum, even if starting from a different ideological perspective. It is also evident that several traditional parties and their leaders, be they in government or not, at different political latitudes, have adopted rhetorics and tones that undoubtedly resemble those of movements and leaders that define themselves as populist. These are clear examples of what Mudde (2004) calls the 'populist Zeitgeist', i.e., that populist discourse has become mainstream in today's politics.

If all politicians are affected by some sort of populist zeitgeist, it is legitimate to ask if there is at least a difference in the intensity of recourse to populist tones, assertions and allusions. One cannot expect leaders like, say, Angela Merkel or Mariano Rajoy, suddenly to convert to a bullying populist language. It is, however, conceivable that they endorse some bellicose demands on behalf of critical sectors of their public opinions that are typically addressed by populist leaders. It is the tone and the presence of some key features of populist discourse that mark the difference.

In this paper, we shall examine social media usage by Italian political actors to determine whether there is a significant difference between populist and mainstream parties such to hypothesise the existence of an 'endemic' sort of populist communication, a sort of 'overflow' of populist discourse into the domestic conventional political discourse.

In the next section, we shall present a more detailed operationalization of the main features of political discourse, applied to political leaders, examined within the context of their usage of social media. Then we will concentrate on the varieties of populism and on their operationalization in empirical research in the section on research design and methodology. In the last section, we will discuss the existence of a socially mediated, endemic populism.

\section{Media, social media and populism: where do we stand?}

Among the challenges facing research on populism pointed out by Aalberg and de Vreese (2017) when introducing a large-scale study on Europe's populisms, there is one of particular

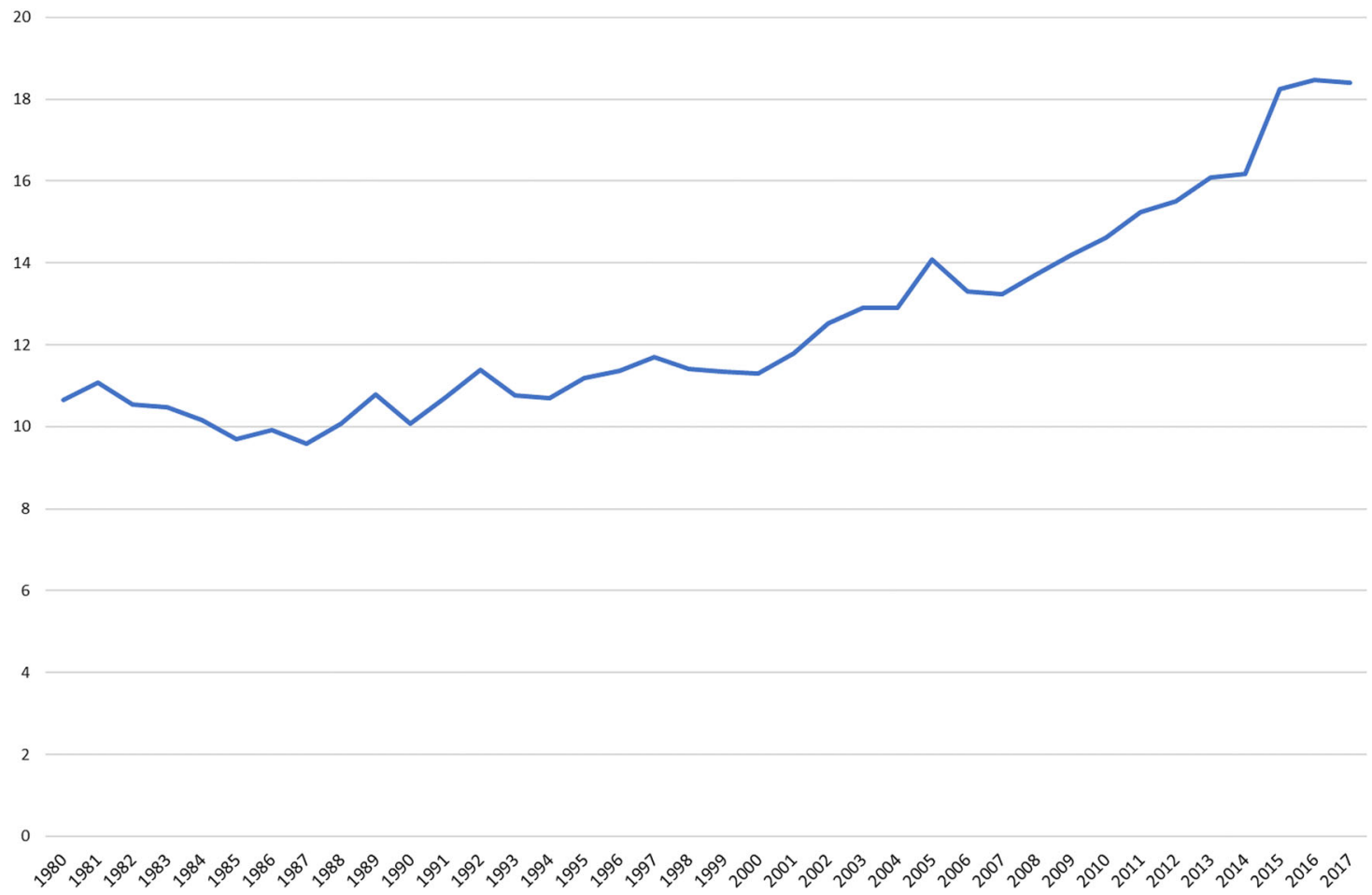

Fig. 1 Average share of votes for populist parties in Europe. The figure shows the average share of votes gained by populist parties from 1980 to 2017. Source: https://www.theatlas.com/charts/Bkmr5DQHW 
importance: 'understanding the extent to which populist discourse enters the mainstream [...]'. (Aalberg and de Vreese, 2017). It is indeed a challenge because any research on populist phenomena has to spell out a definition of what exactly is meant by 'populism'. The term has become lately so popular in academic research that it has generated such a huge volume of scholarly reflection on various designations of (political) populism that one wonders if we are utilising a passe-partout concept. In fact, it covers phenomena unmistakably recognisable as populist as well as phenomena that before the recent academic frenzy were simply identified as protest, conflictual, anti-government actions.

In our study, we do not attempt to put forth a further definition of populism because we draw on the positions worked out by the most recent scholarly debate, like the one in Reinemann et al. (2017), based on a large body of research that highlights the ideological and communicative dimensions of the phenomenon (De Cleen, 2012; Freeden, 2006; Jagers and Walgrave, 2007; Mudde, 2004; Mudde and Rovira Kaltwasser, 2013). Here, populism is taken as 'a general, abstract concept about politics and society that is open to a diverse set of more concrete political ideas and programs, depending on both national and historic contexts' ( $p$ 13). The core features that distinguish it from other ideologies are: (1) the centrality of the idea (or of the ideas) of the 'people' (p 18), around which populists try 'to create a new social identity among citizens [...] in order to unite them and generate a sense of belonging to an imagined community' ( $p$ 19); and (2) the construction of 'the others' as counterparts taking the form of elites and/or out-groups against which the people affirm their preeminence (pp 19-21).

Jagers and Walgrave (2007) have provided some insightful 'measures' of populist communication: empty, exclusionary, antielitist, and complete populism. In our study, we elaborate on their perspective and envisage a continuum from the lowest degree of populism (in politicians' socially mediated/mediatized communication) to the highest degree.

Our core interest is to identify the implications of the link of populist phenomena with the communication eco-systems. Populist leaders and movements have everywhere constantly relied on the visibility and the ensuing popularity assured by the coverage, both critical and supportive, of mainstream and popular media. To be sure, the legacy media keep intact their traditional role, mostly unintentional, of 'king makers' for political figures and movements. However, the communication environment that has been developing with the expansion of the Internet and of digital technology has impressively changed the rules of the game and has made available to political actors an unprecedented abundance of communication tools: new platforms, new outlets, social media with potentially huge publics. Chadwick (2013) has called this new communication landscape 'hybrid' insofar as it merges the mass media and the new digital media into a new indissoluble whole.

The social media are structurally different from traditional media that were and to a large extent still are characterised by the sender-receiver asymmetry. They follow a 'media logic' different from that of television, radio, and print outlets, and in the case of the news industry the media maintain the role of gatekeepers. Digital technology has made it possible to establish interactive relations between senders and receivers, allowing both to bypass the forceful power of mass media.

A 'new media logic' is in play in the political/populist digital communications. It has distinct features with respect to the mass media logic envisaged by Altheide and Snow (1979, 1991). A recent study has provided an interesting theoretical approach to what the authors call 'network media logic' (Klinger and Svensson, 2015), specifically concerning the domain of social media from the three perspectives of production, distribution and usage.
'The network media logic of production is indicative of more individualised forms of media content production compared to mass media where professionals judge what constitutes worthy information or not' ( $p 7$ ). The logic of distribution has to do with the logic of virality ('network-enhanced word of mouth') typical of online social platforms, where 'popularity among like-minded users, not professional gatekeepers, decides whether information is relevant and passed on (i.e., goes viral) or not'. (p 9). Finally, the usage of social media tends to take the form of a communication among the like-minded in 'niche networks based on interest rather than location. So, where mass media consumption to a larger extent is bound to geographically defined communities, social media platforms are bound to communities of peers and like-minded others' ( $\mathrm{p}$ 10).

In the specific case of socially mediated populist communication, the network media logic means that populist leaders' linkage with their constituencies or sympathisers is entirely disintermediated: that is, the production of contents is free from being filtered by journalists or other types of gatekeepers. 'The online environment frequently allows for the circumvention of traditional opinion leaders and facilitates what has been referred to as the 'one-step flow of communication' ' (Engesser et al., 2017: p 1283). At the same time the horizontality and ubiquitousness of social media allow a vast circulation of populist content with high potential impact, thanks to a viral diffusion, if with significant confines in the 'echo-chamber' environment 'where political attitudes are confirmed and amplified', and in the 'homophily' of the Internet, where one observes the 'filter bubble which preselects consonant media content' (Engesser et al. 2017: p 1284).

The disintermediation processes that characterise the hybrid media system (Chadwick, 2013) foster the spread of populist ideology in a fragmented form (Aalberg et al., 2016; Bracciale, Martella, 2017; Engesser et al., 2017; Wirth et al., 2016). This is because political actors directly address citizens by means of social media and, in order to fit their personal action frames (Bennett and Segerberg 2012), blur and fragment populist references in their messages.

If we consider the (mass) media logic as the 'engine' of a mediatisation of politics (Mazzoleni, 2008: p 2932), we might speculate if the 'network media logic' contributes in a similar manner to a new process of mediatisation of politics and, in the case considered here, of political populism. In the new media ecosystem, can we envisage a 'social-media populism' carrying mediatizing effects of populist communication? Certainly, the nature of online digital media boosts the already highly personalised kind of communication of the populist leaders (Engesser et al., 2017, pp 1284-1285). Arguably, social media contribute to dramatising populist communication because they are platforms suited to producing emotional, controversial, even violent contents typical of much populist activism, and to stimulating a 'remix' activity, a creative collage of video clips, sound bites, clickbaits, graffiti, parodies, memes, and many other contents, including insults and fake-news, that can prove crucial in boosting the popularity of the leader, of his/her creed, of his/her movement.

In sum, (1) the individualised form of populist communication via social media, (2) its popularity-geared inclination, (3) its disintermediated nature, (4) its fostering like-minded communities, are to be taken as strong indicators of a distinctive process of mediatisation of political communication. What we see in the specific context of populist leaders' communication, in their followers' usage of social media, in the media coverage of populist events, in the ensuing public debate in the digital public sphere and in off-line environs, is a high-intensity sort of mediatisation, i.e., a 'hyper-mediatisation' of populist communication. This is all the more true in the present hybrid media ecosystem. 
Table 1 Italian political leaders' Facebook pages engagement (1 October 2017)

\begin{tabular}{|c|c|c|c|c|c|c|c|c|}
\hline $\begin{array}{l}\text { Silvio } \\
\text { Berlusconi }\end{array}$ & 940,790 & 263 & $1,136,033$ & $1,215,125$ & 233,837 & 194,032 & $2,779,027$ & 10566.6 \\
\hline Luigi Di Maio & $1,084,813$ & 1130 & $3,731,244$ & $4,048,822$ & 607,499 & $2,340,516$ & $10,728,081$ & 9493.9 \\
\hline Giorgia Meloni & 719,553 & 863 & $2,374,421$ & $2,707,586$ & 412,438 & 809,641 & $6,304,086$ & 7304.9 \\
\hline Matteo Salvini & $1,911,328$ & 851 & $6,950,592$ & $8,219,862$ & $2,286,546$ & $4,418,237$ & $21,875,237$ & 25705.3 \\
\hline Matteo Renzi & $1,080,164$ & 618 & $4,724,452$ & $5,108,105$ & $1,602,670$ & 689,723 & $12,124,950$ & 19619.7 \\
\hline
\end{tabular}

\section{Research design and methodology}

Research questions. The consequences for the political communication of any new or established leader or party, and especially of how populist actors exploit the hybrid communication environment, are significant-as testified by the extant copious scholarly production. Reflections on the features of populist communication in the social media environment raise specific questions that we have tried to address in empirical research conducted on the Italian political leaders.

RQ1. Is it possible to identify the existence of an 'endemic populism' in social media as used by political actors?

RQ2. What are the specific aspects of socially mediated populism?

RQ3. What are the different degrees of populism in the rhetoric used by leaders on Facebook social media?

Case selection. To answer the research questions, we analysed the Facebook timelines of the following Italian political leaders, who stand out as the most noticeable in the domestic political arena: Silvio Berlusconi (leader of the centre-right party Forza Italia), Luigi Di Maio (front-runner of the Five Stars Movement), Giorgia Meloni (leader of the far-right party Brothers of Italy), Matteo Salvini (leader of the right-wing party Northern League), and Matteo Renzi (leader of the Democratic Party).

According to the existing literature, three of these parties are considered populist: the Five Stars Movement because of its historical opposition to traditional parties and media, regarded as a single corrupt entity (Bordignon and Ceccarini, 2013); the Northern League due to its political message against political and economic élites and its constant appeal to the 'people' identified on ethnic bases (Albertazzi and McDonnell, 2008) so much so that it is called 'an almost ideal-type incarnation of populism' (Tarchi, 2015a, b: p 243); and Forza Italia and Silvio Berlusconi, these being defined as neoliberal populists (Bobba and McDonnell, 2016), often 'accusing the elite (i.e., mainstream parties and trade unions) of frustrating the hard-working common people with unnecessary laws and high taxes' (Mudde and Rovira Kaltwasser, 2017: p 35).

The other leaders are also interesting cases because, even though they are not immediately acknowledged as populist actors, their political ideas and their rhetoric often espouse typical populist stances. Brothers of Italy, an ally of Berlusconi's centreright coalition, is an offshoot of the former leading party of the right, Alleanza Nazionale, whose ideology has been defined nationalist but not populist (Tarchi, 2015a, b). The Democratic Party is 'by definition' a liberal, moderate, anti-populist formation. However, its leader's speeches have often targeted certain elites and the Democratic Party's old leadership with bullying accents. Matteo Renzi regarded his struggle to seize the party's leadership as a clash between innovators and conservatives, young against old, etc. (Bordignon, 2014).
Sample. In Italy, there are 43 million Internet users; 34 million social media users and 34 million active users monthly on Facebook. This means that social media users in Italy are almost entirely also Facebook users.

All the principal Italian political leaders have a Facebook page. The Facebook timelines of the above five leaders, dating from 1 October 2016 to 1 October 2017, were downloaded through Facebook Graph API. In total we collected 3725 posts (Table 1).

If we look at the engagement generated by the posts of the political leaders, we can highlight that every post received a minimum average of over 7000 interactions (Giorgia Meloni), and a maximum of more than 25000 (Matteo Salvini).

It is evident that Italian internet users are very active on Facebook: in 1 year the five leaders received more than 53 million interactions (that is, likes, reactions, comments and sharing) from their followers, compared with 34 million social media users estimated in Italy.

In order to subset the entire database for the analysis, Facebook posts were sampled according to the distribution of received shares: for each leader, we selected the most shared posts (the posts in the first percentile of distribution for number of shares received). We chose this criterion for selection because, given the specific affordances of Facebook, the more posts are shared, the more they become visible on the social media platform, and the politicians' posts can reach the broad public through the public interactions (Bene, 2017). Accordingly, 934 posts were analysed: Berlusconi, 66; Di Maio, 283; Meloni, 216; Renzi, 156; Salvini, 213.

The posts were analysed by searching for the presence of populist ideology fragments. All posts were coded by two trained coders, ${ }^{1}$ who used a content analysis coding schema built according the following systematisation of the populist ideology. Indicators were transformed into a set of dichotomous variables in order to highlight the presence (1), or the absence (0), of each indicator in a leader's posts. The indicators are not mutually exclusive.

\section{Measuring the degree of populist communicative ideology}

Drawing on the most recent literature on populism as communication style (Aalberg et al., 2016; Bracciale and Martella, 2017; Bobba, 2018; Cranmer, 2011; Engesser et al., 2017; Jagers and Walgrave, 2007; Wirth et al., 2016), populist ideology was broken down into the following dimensions: (1) Appeal to 'the people'; (2) Attacking the élite; and (3) Ostracising the others. For each dimension we provide an example from the message data sets analysed.

Appeal to 'the people'. 'Appeal to the people' means referring to the people in a manner that presumes or calls upon their consent. The word 'people' is a catch-all expression that politicians use, irrespective of their political affiliation, to unite the electorate.

The construction of 'the people' means: 'appeals to the people, talking about the people, putting the people and their options first in political decisions, or symbolically and rhetorically uniting 
with the people by talking about 'we' and 'us' ' (Aalberg et al., 2016; Akkerman et al., 2014; Alvares and Dahlgren, 2016; Biorcio, 2015; Canovan, 1999; Engesser et al., 2017; Hawkins et al., 2012; Krämer, 2014; Kriesi, 2014; Laclau, 2005; Mény and Surel, 2002; Mudde, 2004; Mudde and Rovira Kaltwasser, 2017; Taggart, 2000; Wirth et al., 2016). Considering that all politicians-more so now that they have access to social media-refer to and talk about the people almost all the time (Jagers and Walgrave, 2007), we identified some sub-dimensions of the most common construction of 'the people' according to the literature, and searched for their presence in our leaders' Facebook posts.

a. Sovereignty: 'the people' is the ultimate democratic sovereign or the 'ruler' often betrayed by the elites. Thus, the people's will is a fundamental principle for political actors that depict themselves as advocates of the people's rights. In this sense, direct democracy is a typical theme of the populist discourse addressing the people as sovereign.

Silvio Berlusconi-7 August 2017

[...] above all, I feel the suffering of Italians who feel unsafe in their homes, harassed by taxes, disillusioned with politics and anti-politics. And I feel a great responsibility. More and more Italians are asking me, at Forza Italia, on the centreright, to radically change things that are wrong in our country. To put an end to fiscal oppression, bureaucratic oppression and judicial oppression.

Giorgia Meloni-24 November 2016

[.... I think that it will be a good day for the Italians the day when they can recover their sovereignty and can choose their governments and when we will no longer have an executive of lobbies and Merkel but a government of Italy and the Italians[...].

Matteo Renzi-30 April 2017

[....] if it had gone otherwise, Italy would today be stronger in Europe and beyond. And politics would not be stagnating in a swamp of embarrassing delays with timewasting on the electoral law. But the people have decided and the people are always right.

b. Class: political actors refer to the people as 'underprivileged citizens who differ from the elites mainly with respect to their economic situation, formal education and access to power' (Reinemann et al., 2017: p 17). Accordingly, 'the people' are depicted as a deprived socio-economic class or subset of the population (i.e., hard-working citizens, artisans, retirees, etc.) disregarded by governments and political elites.

Luigi Di Maio-2 February 2017

[.... Here we are witnessing the massacre of a generation now supposed to split the world. The members of parliament don't give a toss about all this because they get high pensions at the age of 65 for having worked for just four and a half years and are offended if you tell them that it is a life annuity and a privilege[...].

Matteo Renzi-4 April 2017

If I could go back, not only would I redo the $80 €$ but I would raise the bonus to 100 because this measure served to restore purchasing power to families. In fact the middle class appreciates it, the super rich such as Berlusconi and Grillo do not!

c. Nation/Ethnic group: here 'the people' is understood as a national community or ethnic group, with emphasis on belonging to the native population as the main criterion to discriminate who is part or not part of the nation.

Matteo Salvini-14 November 2016

Thanks to the Renzi government, illegal immigrants are enjoying hotel accommodation, while Italians are homeless. Also for this reason on 4 December \#Ivoteno

Silvio Berlusconi-07 July 2017

The Democratic Party is insisting by all means on enactment of the new Ius Soli law. It is a wrong law that the Italians do not want and that has nothing to do with reception. We want it to be possible for those who feel truly Italian to become Italian, not those who have only gone through a few bureaucratic steps. Perhaps the Democratic Party hopes to create a pool of new voters in this way. There is even talk of 800,000 people. If so I must say that it is a short-sighted and also cynical calculation on the skin of Italians

d. Cultural: the people is 'our people' not based on formal citizenship or ethnicity but rather on shared and common values, religion, history, customs.

Matteo Renzi-29 October 2016

It was a wonderful party of a people that does not scream, that does not insult. Doing politics means proposing, not just saying No \#weTakeTheStreets

Matteo Renzi-14 April 2017

[....] we are not just sharing a video or news item. We are sharing a political idea that is based on proposal and not on protest. That is based on true documents and not on false signatures. That creates concrete projects for the country not evidence invented against someone. We are like this: a community of women and men who try to demonstrate every day step by step that you can change things without moaning and screaming.

Matteo Salvini-6 June 2017

Were I in government tomorrow morning I would NOT concede even half a square metre to the Islamic communities until they sign black on white that WOMEN have the same RIGHTS as men. Is that understood? THIS IS HOW IT WORKS AT OUR HOME!

Giorgia Meloni-19 August 2017

What can we do to combat Islamic terrorism? As Brothers of Italy-National Alliance, we have been repeating it for years: 1. Prohibit Islamic fundamentalist propaganda such as the Salafite and Wahabi propaganda of Saudi Arabia and Qatar, which theorise the use of violence against infidels; 2. Stop immigration from countries with an Islamic majority; 3. Allow foreigners who share and respect our culture to stay in Europe; the others must return home, 4. Do not 
automatically grant citizenship, but only to those who demonstrate their willingness to integrate. More than ius soli! 5. Assert our Greek, Roman and Christian roots and make it clear that we will never resign ourselves to the islamisation of Europe.

Attacking the élite. This second dimension of the concept of populism is built on anti-elitism and anti-establishment stances. It refers to the typical populist rhetoric that emphasises the distance between 'us' and 'them'. 'Us' stands for the common citizen and 'them' represents the common enemy established by the dominant elite, which may sometimes be identified under different headings (politics, media, economic powers, etc.). According to a Manichean view of society elites are corrupt, exploitative, and disrespectful of the real interests and needs of the people (Akkerman et al., 2014; Albertazzi and McDonnell, 2008; Biorcio, 2015; Bos et al., 2013; Caiani and Graziano, 2016; Canovan, 1981; Hawkins et al., 2012; Jagers and Walgrave, 2007; Mény and Surel, 2002; Mudde, 2004; Taggart, 2000; van Kessel and Castelein, 2016; Wirth et al., 2016). Targeted elites can vary according to the context and the aims of the political actors: political, economic, institutional, media, intellectuals, etc.

Giorgia Meloni-9 September 2016

In the U.S. the people won against the elites, the oligarchies, high finance and the dominant ideology. The same will happen in Italy on 4 December: Italian citizens will not listen to radical-chic people but will vote against this government, which has not been elected, in order to regain their sovereignty.

Luigi Di Maio-22 March 2017

They have just rejected our proposal to eliminate the privileged pension of parliamentarians. It is a shame. They chose to stay in the Middle Ages. We shall create another country together with our citizens.

Matteo Renzi-16 June 2017

The umpteenth transport strike is a scandal. Yet another one on Friday. It was proclaimed by small trade unions, which once again use the alibi of privatisation. In Florence, 5 years ago, we put the service out to tender, and a public company, the State Railways, won the contract. More can be done, but now they manage it better than in the past. Rather than three cable-cars, perhaps the Romans would prefer to have a regular bus every 5 min: putting the service to tender would cause the autonomous trade unions to lose votes, but it would improve the lives of citizens. And in this delicate tourist season: how can Alitalia be left on the ground again? The right to strike is sacrosanct and must be guaranteed. But also the citizens have a right not to be mocked: it is not possible for a myriad of small trade unions to paralyse Fridays in our cities.

Ostracising the others. 'Ostracising the others' involves a narrative based on the 'dangerous others' concept that targets a common enemy within groups of the population that are stigmatised and excluded from 'the people'. This is a new contraposition between 'us', 'the people' as a homogenous category, and 'them', an enemy within the people. These out-groups are perceived as uniform and usually regarded as inferior. Dangerous others are often depicted as a threat and addressed by political actors as scapegoats. (Aalberg et al., 2016; Biorcio, 2015; Cranmer, 2011; Jagers and Walgrave, 2007; Mudde, 2004; Wirth et al., 2016; Abts and Rummens, 2007; Mudde and Rovira Kaltwasser, 2017).

Ostracism towards out-groups can be expressed in two different ways:

a. Dangerous others: political actors identify isolated groups within the people as an internal enemy; stigmatising and excluding segments of the people from the specific population.

Giorgia Meloni-28 July 2017

Three bastard fake refugees, supported by Italians' money, raped a 14-year-old girl in Trieste. [...] Enough with out of control immigration, enough with being fooled by illegal immigrants passed off as refugees. [...]

Luigi Di Maio-10 April 2017

Italy has imported from Romania $40 \%$ of its criminals. While Romania is importing our companies and capital from Italy. What about this EU! Since in Italy politics has never wanted to make justice work-on the contrary, very often it has deliberately sabotaged it-we are attracting criminals while our businesses flee to where the judicial systems are more efficient: as in Romania!

b. Authoritarianism: this is when political actors press for severe political measures or illiberal policies against those who threaten the homogeneity of the people.

\section{Matteo Salvini-1 March 2017}

1) chemical castration for paedophiles and rapists, whether Italian or foreign, as in many civilised countries: you do it once and you'll never do it again!

2) abolish the offence of excessive self-defence: if you come into my house, I will kill you before you can attack me!

3) Women's Day is only a manifestation of hypocrisy if SERIOUS LAWS are not enacted; certain BEASTS have to go to PRISON (and throw away the key!).

Giorgia Meloni-19 January 2017

An army of 34 thousand potential terrorists has landed in Europe together with illegal immigrants. Europol has said this, not some insane populist [....]. We are not prepared to allow ourselves to be invaded without reacting: stop landings and create a naval blockade off the Libyan coast to prevent the boats from leaving. The rest is complicity with terrorists.

A populism index. Based on the above three dimensions we then constructed a synthetic 'Populism Index' showing the different extents to which populist ideology is espoused by leaders on Facebook. In accordance with the idea that populist ideology in social media spreads in fragmented forms, we considered as populist every post that contained at least one populist reference.

The additive index ranges from 0 , which means absence of populist references, to 3, which corresponds to the presence of all the above-mentioned dimensions of populism in the leaders' Facebook posts:

- zero-level of populism: the posts do not contain any populist references (value of index $=0$ ); 
$60.0 \%$

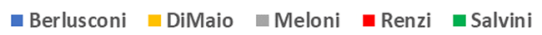

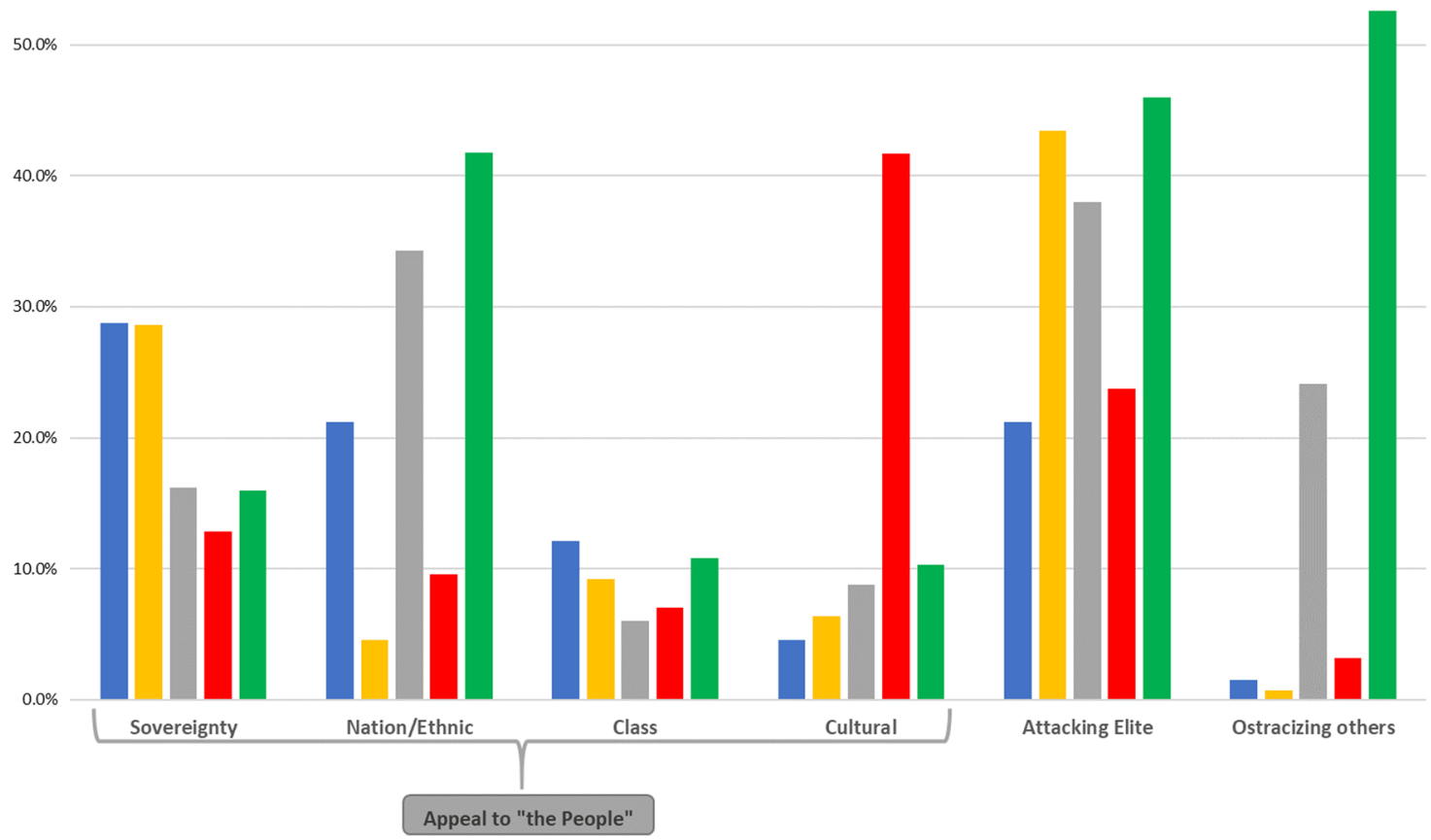

Fig. 2 Populist ideology fragments in the Italian political leaders' Facebook posts. This figure shows the percentage of each indicator of the populist 'thin' ideology in the analysed leaders' Facebook posts. Each colour corresponds to one leader as shown in the legend

- soft populism: the posts contain only one populist reference among the dimensions that build the populist ideology (value of index $=1$ );

- moderate populism: the posts contain a combination of two populist references (value of index $=2$ );

- bold populism: the posts contain all three populist references: appeal to 'the people', attacking the elite, and ostracising the others (value of index $=3$ ).

Findings. Data from the content analysis shows that in $67 \%$ of the posts there is at least one of the three dimensions of populist ideology.

This first finding confirms the existence of what we have hypothesised as an 'endemic populism' among all the leaders, because more than half of the posts contain references to populist issues (RQ1). Matteo Renzi also uses fragments of ideology in $62 \%$ of his posts, confirming the idea that 'going public' through social media fits very well with the populist discourse.

Over and above this aggregate result, the indicators of each dimension disclose a very differentiated adoption of populist fragments by each leader (Fig. 2).

As expected, the 'appeal to the people' is the most frequent ideology fragment (59\%). The different meanings of the dimension afford better understanding of how 'the people' is identified and rhetorically constructed, and make it possible to answer the second research question (RQ2) by highlighting several aspects of the socially mediated populism of the Italian leaders.

The 'Emphasis on Sovereignty' is mainly used by Silvio Berlusconi (29\%) and Luigi Di Maio (29\%). Through this rhetorical construction, leaders try to engage people as the actual depositaries of sovereignty, and legitimate themselves as advocates of the people's will. In this sense, the emphasis on sovereignty represents a characteristic of 'soft populism', which in this case is interpreted in two different ways: advocacy by Silvio Berlusconi (in defence of the people), and legitimisation by Luigi Di Maio (stressing the direct democracy issue in his claim).
The construction of the people as Nation or Ethnicity is above all adopted by right-wing leaders, and its use gradually increases on shifting from the centre-right to the far-right: Silvio Berlusconi (centre-right, 21\%); Giorgia Meloni (nationalist right-wing, 34\%); and Matteo Salvini (xenophobic right-wing, 42\%).

The appeal to the people as a socio-economic class is also adopted by Silvio Berlusconi (12\%) followed by Matteo Salvini (11\%) and Luigi Di Maio (9\%). In this meaning, 'the people' addressed is composed of subsets of the whole population, often depicted as abandoned by governments.

This is not a surprising finding in regard to the Northern League, because this meaning of 'the people' has always been a typical trait of its political discourse. In fact, since the beginning of its history the party has constantly referred to the virtuous, hard-working small entrepreneur [...] craftsmen and small tradesmen struggling against major supermarket chains and banks (that is, the powers-that-be who would strangle them)' (Tarchi, 2008: pp 90-91)

The most unexpected result, which confirms the existence of an 'endemic populism', is the adoption of many populist references by Matteo Renzi, who is leader of an anything but populist party. For this reason, we provide some additional explanation of his case. Renzi tends to use the word 'people' in a cultural sense, i.e., based on shared values, beliefs, behaviours and aims. Since the beginning of his leadership his political message has been characterised by pairs of opposites used to stage the contraposition between him (and 'his people') and various enemies. In fact, Matteo Renzi «presents himself as the homo novus who has gone against the 'old boys' of the PD» (Pasquino, 2016: p 392) trying to draw a line between himself and the Italian politicians, above all the old Democratic Party's nomenklatura. These contrapositions are rhetorically summarised by Renzi himself with the expression 'scrapping' (rottamazione), by which is meant the sacking of the old political establishment starting from that of the Democratic Party. 
Many scholars have defined Renzi as populist ('light populist', 'populist from above', 'constructive populist', etc.) due to several nuances of his political ideas, style and rhetoric (Bobba and Legnante, 2016; Bordignon, 2014; Ceccarini and Bordignon, 2017; Salvati, 2016; Tarchi, 2015a, b). Firstly, he has always expressed the intent to transform the Democratic Party into a leadercentred party (Bordignon, 2014) and a catch-all party (the party of the nation) (Pasquino, 2016) also according to his predilection for rapid decision making. The direct connection with the people, bypassing intermediaries like parties or trade unions is a wellknown populist trait.

According to recent analyses of Matteo Renzi's discourse (Bordignon, 2014), his style and rhetoric are often characterised by the typical populist construction of 'us against them' in which 'them' are often depicted as 'enemies of change' (Salvati, 2016) and 'us' change according to the political context or the aims of the Democratic Party leader (i.e., citizens, local administrators, etc.). Renzi has applied this rhetorical contraposition also against trade unions accused of being inefficient and self-referential elites no longer representative (Bordignon, 2014; Salvati, 2016) and against 'jumped-up professors' (labelled 'owls' or 'canapé eaters') who criticise his reform projects (Tarchi, 2015a, b). Indeed, like Silvio Berlusconi with the People of Freedom party, Matteo Renzi was party secretary and Prime Minister at the same time, ruling both the party and the government to the extent that some scholars have highlighted this phenomenon as 'presidentialization of politics' in the case of the Democratic Party (Fasano and Seddone, 2016; Seddone and Venturino, 2015). Furthermore, he has extremely personalised politics by introducing a new dimension of personalisation in a left-wing party (Seddone and Venturino, 2015) to the extent that even the last referendum on his constitutional reforms (4th December 2016) became a popular vote on Matteo Renzi's leadership (Ceccarini and Bordignon, 2017).

All these elements can be found in his Facebook posts, sometimes in watered-down versions due to the change of his communicative strategy during the referendum campaign, above all by using «antithetical categories that delineate a dichotomous representation of reality» (Bordignon, 2014: p 17) like young or new vs. old, love vs. hate, courage vs. fear, beautiful vs. ugly.

Four out of ten of his posts are characterised by this contraposition, which changes according to the enemy of the moment or the specific issue concerned (science vs. witchery about vaccines, innovators vs. conservatives labelled as owls or envious people, etc.).

Since his leadership is considered 'divisive' in Italy, Renzi needs to directly address and appeal to this rhetorically constructed community in order to cope with extra and intra-party antagonism. This result appears coherent with the hypotheses that also non-populist actors do not disdain from using populist references in social media and that differences among leaders emerge rather in the degree of populism (in the variety and quantity of populist references used).

The other dimensions of populist ideology are generally less present in the leaders' posts compared to the 'Appeal to the people': Attacking the elites (38\%) and Ostracising Others (18\%).

The most active in attacking the élites are clearly the hardline populists Matteo Salvini (46\%), Luigi Di Maio (43\%) and Giorgia Meloni (38\%). Quite unexpectedly, Matteo Renzi, too, attacks the élites-accusing them of being distant from the people-and the media $(23 \%)^{2}$.

The last dimension, which refers to the rhetorical construction of the 'dangerous others', is a typical feature of the nationalist and xenophobic right-wing formations. Matteo Salvini's (53\%) narrative is imbued with such references: he turns every news item into attacks on immigrants and refugees, almost always referred to as 'illegal immigrants'. Indeed, the vociferous leader of the Northern League often shares news and videos that depict 'immigrants' as dangerous people opposed to (or in competition with) national Italians. Giorgia Meloni's posts appear less replete with this rhetoric (24\%), although she joined Salvini in the harsh political battle against the so called 'ius soli' (law granting citizenship to immigrants born on Italian soil).

The analysis carried out thus far has identified the typical features of populist communication, but it has not yet shown the 'degree of populism' with which leaders address their audiences. In order to take these differences into account and to answer the third research question (RQ3), we used the 'Populism Index' previously outlined.

Overall, in Fig. 3, Silvio Berlusconi's and Matteo Renzi's communication on Facebook emerges as the most 'soft populist'. Giorgia Meloni's and Luigi Di Maio's communication via social media is characterised by a 'moderate populism' level. Finally, Matteo Salvini's communication is a good example of what we identify as 'bold populism'.

\section{Discussion and conclusion: a socially mediated, endemic populism?}

The case of Italian populist and non-populist leaders that actively use social media in their political communication is undoubtedly just one of the several cases to be found in Europe's national contexts.

The phase of experimenting-with some apprehension and ineptness by users-with the new outlets that immensely empowered political communicators is now past. Facebook and Twitter have become familiar platforms for both politicians and citizens to articulate their comments or make their voices heard, at times quite effectively. Populists are no exception. On the contrary, populist communicators, more than other mainstream party figures, can exploit to their great advantage the disintermediate nature of social media to offset hostile editorial coverage by mainstream media. That is not to say that they are blocked from access to the big media. As noted, their populist action, often accompanied by flamboyant personality traits, and above all by their widely recognised skills as newsmakers, secure large popular visibility. This is certainly the case of Italian populist leaders, like Berlusconi, Di Maio, Salvini and Meloni. Their presence on popular television talk shows is constant and intensive. Hosts compete to have them in their studios every night. Yet, it appears that beside and beyond that substantial free publicity they need to maintain direct contact with their constituencies, resorting to a likewise intense dialogue by means of the social media. This is an example of a hyper-mediatized sort of populist communication, typical of a hybrid media environment.

From our analysis there emerges some significant evidence of what we have called 'endemic populism' displayed by nonpopulist leaders (e.g., the leader of the Democratic Party) who do not disdain coupling populist narratives (like the 'us' vs. 'them' opposition) with more conventional political disputes. Both the stark populist socially mediated communication and the populistsounding communication of 'occasional' populists assume nuanced patterns that reflect the degree of populism of their respective political formations.

The several meanings of 'the appeal to the people' make it possible to highlight the differences among leaders' rhetorical construction of the polarisation between 'us' and 'them'. These qualitative differences relate to the party's key topics and the specific context or issue addressed. For example, Giorgia Meloni and Matteo Salvini both identify the people on national/ethnic bases, but while the leader of the Northern League prefers to counterpose 'Italians' to illegal immigrants, the leader of Brothers 


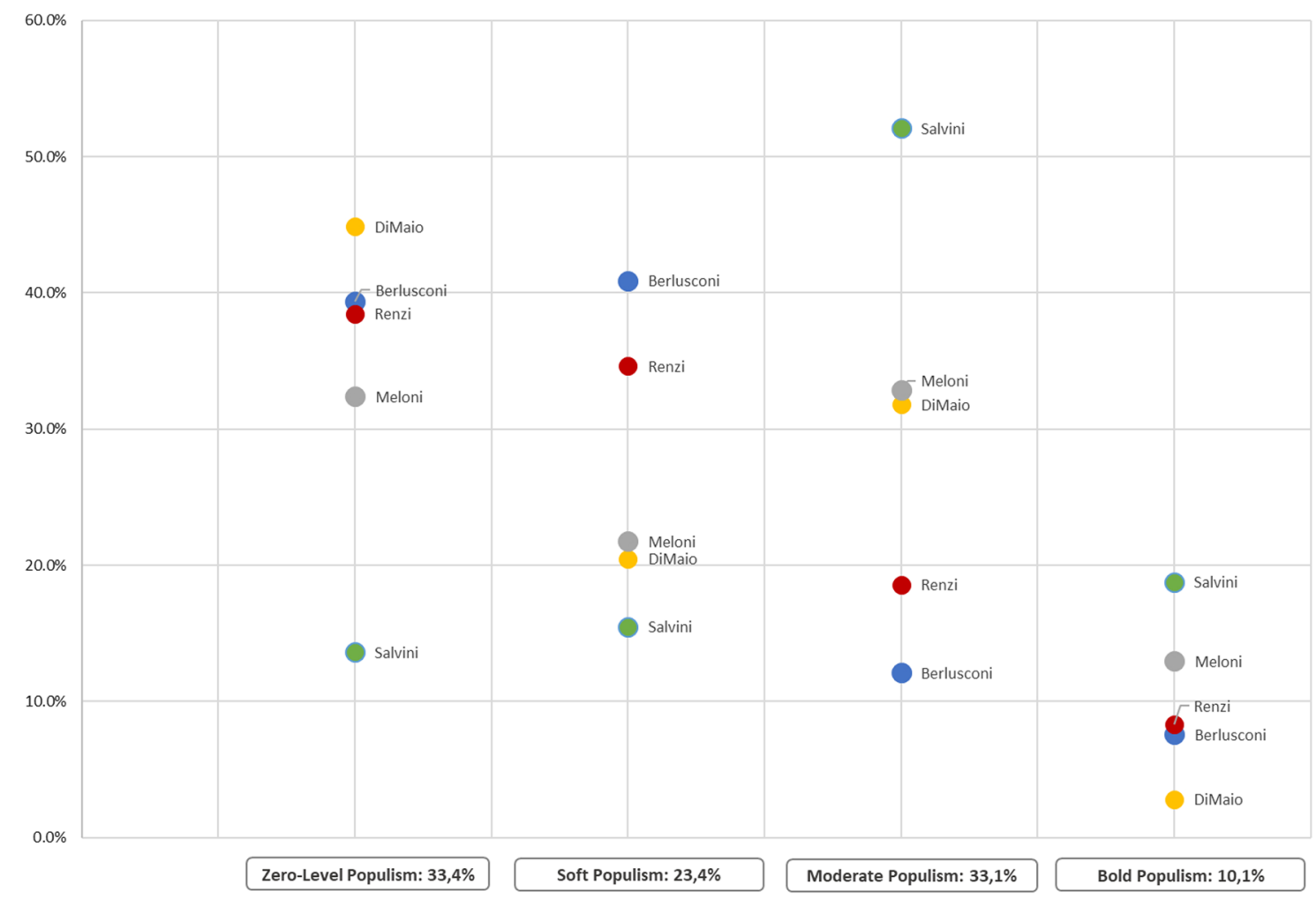

Fig. 3 Degrees of populism in Italy's politicians' Facebook communication. This figure shows the average of Facebook posts for each leader grouped by level of populism. Soft Populism indicates the presence of one populist ideology fragment; Moderate Populism posts contain two populist ideology fragments; and Bold Populism means that posts include three populist ideology fragments

of Italy often sets 'Italians' in opposition to the government or élites in general. On the other hand, Luigi Di Maio and Silvio Berlusconi both prefer to 'invoke the people' as the actual sovereign even though the 5 Stars Movement leader is more used to opposing this people to the ruling élites in wrapping his messages on Facebook. The case of Matteo Renzi is very interesting because even though he often adopts a populist narrative represented by the rhetorical construction of 'us' against 'them', he identifies 'the people' on cultural bases unlike the other leaders. His 'performance' not only confirms the presence of an 'endemic populism' that overflows from strictly populist precincts into the general political discourse, but also shows that populist references are often used as a communication strategy by the main Italian leaders.

Moreover, the 'Populism Index' shows the relationship among Italian leaders and the three core aspects of populism can be understood as a 'thin ideology' (Mudde, 2004). This relationship, represented by the different levels of populism (light, moderate and bold), on the one hand highlights each leader's communicative choices represented by the different degree of populism in their posts. On the other hand, it confirms that it can be very difficult to identify specific actors as sheer populists or nonpopulists. This is because the fragmentation of the populist ideology and the strong polarisation, typical of the social media environment, perfectly fit with the adoption of one or more populist references according to leaders' aims and communicative strategies (Bracciale and Martella, 2017).

Lastly, there seems to emerge a political cleavage in the different degrees of populist communication adopted by Italian leaders. Centre-right and centre-left leaders (Silvio Berlusconi and Matteo Renzi, respectively) prefer a 'Soft Populist' communication; extreme-right leaders (Giorgia Meloni and Matteo Salvini) post more 'Bold Populist' messages. Indeed, all the opposition parties' leaders (Di Maio, Meloni, Salvini) are characterised by a 'Moderate or Bold Populist' communication. This means that 'Soft Populism' is the communicative trait of the Italian mainstream parties, in spite of the 'Moderate or Bold Populism' that appears to be the communicative characteristic of the opposition parties. This behaviour arguably relates to the intimate core of populism: the rhetorical construction of 'us' against 'them' works perfectly as a tool of attack and contraposition that fosters the 'hyper-mediatisation' of the populist messages and fits with opposition parties' aims. 'Bold Populist' communication is more common among extreme-right parties' leaders, above all in Matteo Salvini's posts. This last result is very similar to what already emerged in Jagers and Walgrave (2007) about Vlaams Blok communication and 'complete populism', confirming in some way the validity of the index and its possible applicability to different national contexts.

The Italian case undoubtedly shows that in a hybrid media context and hyper-mediatized environment, socially mediated populist communication has very distinctive characteristics. Studying them more closely can help to further understand populism, its features, its degrees, its reach in society and in politics.

Received: 10 December 2017 Accepted: 26 March 2018

Published online: 24 April 2018

\section{Notes}

1 The coefficients of Krippendorff's $\alpha$ for the groups were highly satisfactory in terms of almost all variables (Krippendorff's $\alpha>0.79$ and Percent agreement $=97 \%$ ) by convention established in the field (Hayes and Krippendorff, 2007).

2 Italian media covered in a sensationalist way the judicial investigation of Renzi's father, suspected in February 2017 of trafficking in influence (a criminal offence). 


\section{References}

Aalberg T, de Vreese CH (2017) Introduction: Comprehending populist political communication. In: Aalberg T, Esser F, Reinemann C, et al. (eds) Populist political communication in Europe. Routledge, New York, NY, pp 3-11

Aalberg T, Esser F, Reinemann C, et al. (eds) (2016) Populist political communication in Europe. Routledge, New York, NY, London

Akkerman A, Mudde C, Zaslove A (2014) How populist are the people? measuring populist attitudes in voters. Comp Political Stud 47(9):1324-1353

Albertazzi D, McDonnell D (eds) (2008) Twenty-first century populism. The spectre of western European democracy. Palgrave Macmillan, Basingstoke

Altheide DL, Snow RP (1979) Media logic. SAGE, Beverly Hills

Altheide DL, Snow RP (1991) Media worlds in the postjournalism era. Aldine de Gruyter, New York, NY

Alvares C, Dahlgren P (2016) Populism, extremism and media: Mapping an uncertain terrain. Eur J Commun 31(1):46-57

Bene M (2017) Go viral on the Facebook! Interactions between candidates and followers on Facebook during the Hungarian general election campaign of 2014. Inf, Commun Soc 20(4):513-529

Bennett WL, Segerberg A (2012) The logic of connective action. Inf, Commun Soc 15(5):739-768

Biorcio R (2015) Il Populismo nella politica italiana. Da Bossi a Berlusconi, da Grillo a Renzi. Mimesis, Milano

Blumler JG, Kavanagh D (1999) The third age of political communication: influences and features. Political Commun 16(3):209-230

Bobba, G (2018) Social media populism: features and 'likeability' of Lega Nord communication on Facebook. European Political Science, https://doi.org/ 10.1057/s41304-017-0141-8

Bobba G, Legnante G (2016) Italy: A breeding ground for populist political communication. In: Aalberg T, Esser F, Reinemann C, Stromback J, De Vreese C (eds) Populist political communication in Europe. Routledge, New York, NY, pp 221-234

Bobba G, McDonnell D (2016) Different types of right-wing populist discourse in government and opposition: The case of Italy. South Eur Soc Polit, Routledge 21(3):281-299

Bordignon F (2014) Matteo Renzi: A 'Leftist Berlusconi' for the Italian democratic party? South Eur Soc Polit 19(1):1-23

Bordignon F, Ceccarini L (2013) Five stars and a cricket. Beppe Grillo shakes Italian politics. South Eur Soc Polit 18(4):427-449

Bos L, van der Brug W, de Vreese CH (2013) An experimental test of the impact of style and rhetoric on the perception of right-wing populist and mainstream party leaders. Acta Polit 48(2):192-208

Bracciale R, Martella A (2017) Define the populist political communication style: the case of Italian political leaders on Twitter. Inf, Commun Soc 20 (09):1310-1329

Caiani M, Graziano PR (2016) Varieties of populism: insights from the Italian case. Ital Political Sci Rev/Riv Ital di Sci Polit 46(2):1-25

Ceccarini L, Bordignon F (2017) Referendum on Renzi: The 2016 vote on the Italian constitutional revision. South Eur Soc Polit 22(3):281-302

Canovan M (1981) Populism. Junction, London

Canovan M (1999) Trust the people! Populism and the two faces of democracy. Political Stud 47(1):2-16

Chadwick A (2011) The political information cycle in a hybrid news system: The british prime minister and the 'Bullygate' affair. Int J Press/Polit 16(1):3-29

Chadwick A (2013) The hybrid media system. Oxford University Press, Oxford

Cranmer M (2011) Populist communication and publicity: an empirical study of contextual differences in Switzerland. Swiss Political Sci Rev 17(3):286-307

De Cleen B (2012) Populism as a strategy to deal with criticism from non partypolitical actors: The Vlaams Belang and the delegitimization of critical artists. In: Paper presented at the Fourth European Communication Conference. Istanbul, Turkey. 23-25 October 2012, Istanbul

Engesser S, Ernst N, Esser F et al. (2017) Populism and social media: how politicians spread a fragmented ideology. Inf, Commun Soc 20(8):1109-1126

Engesser S, Fawzi N, Larsson AO (2017) Populist online communication: introduction to the special issue. Inf, Commun Soc 20(9):1279-1292

Fasano LM, Seddone A (2016) Selecting the leader, Italian style. Contemp Ital Polit $8(1): 83-102$

Freeden M (2006) Ideology and political theory. J Political Ideol 11(1):3-22

Hawkins K, Riding S, Mudde C (2012) Measuring Populist Attitudes. Political concepts committee on concepts and methods. Available from: http://www. concepts-methods.org/Files/WorkingPaper/

PC_55_Hawkins_Riding_Mudde.pdf.

Hayes AF, Krippendorff K (2007) Answering the call for a standard reliability measure for coding data. Commun Methods Meas 1(1):77-89

Jagers J, Walgrave S (2007) Populism as political communication style: An empirical study of political parties' discourse in Belgium. Eur J Political Res 46(3):319-345

Klinger U, Svensson J (2015) The emergence of network media logic in political communication: A theoretical approach. New Media Soc 17(8):1241-1257
Krämer B (2014) Media populism: A conceptual clarification and some theses on its effects. Commun Theory 24(1):42-60

Kriesi H (2014) The populist challenge. West Eur Polit 37(2):361-378

Laclau E (2005) On populist reason. Verso, London, New York, NY

Mazzoleni G (2008) Media logic. In: Donsbach W (ed), The International Encyclopedia of Communication, Wiley-Blackwell, Malden, MA, pp 2930-2932

Mazzoleni G (2014) Mediatization and political populism. In: Esser F, Strömbäck J (eds) Mediatization of politics. Understanding the transformation of western democracies. Palgrave Macmillan, London, New York, NY, pp 42-56

Mény Y, Surel Y (eds) (2002) Democracies and the populist challenge. Democracies and the populist challenge. Palgrave Macmillan, London

Mudde C (2004) The populist zeitgeist. Gov Oppos 39(4):542-563

Mudde C, Rovira Kaltwasser C (2013) Exclusionary vs. inclusionary populism: comparing contemporary Europe and Latin America. Gov Oppos 48(2):147-174

Mudde C, Rovira Kaltwasser C (2017) Populism: A very short Introduction. Oxford University Press, Oxford

Pasquino G (2016) Renzi: the government, the party, the future of Italian politics. J Mod Ital Stud 21(3):389-398

Reinemann C, Aalberg T, Esser F et al. (2017) Populist political communication: Toward a model of its causes, forms, and effects. In: Aalberg T, Esser F, Reinemann C, et al. (eds) Populist communication in Europe. Routledge, New York, NY, pp 12-28

Rooduijn M (2014) The mesmerising message: The diffusion of populism in public debates in western European media. Political Stud 62(4):726-744

Salvati E (2016) Matteo Renzi: a new leadership style for the Italian Democratic Party and Italian politics. Mod Italy 21(1):7-18

Seddone A, Venturino F (2015) The partito democratico after the 2013 elections: all change? J Mod Ital Stud 20(4):474-490

Street J (1997) Politics and popular culture. Polity Press, Oxford

Taggart P (2000) Populism. Open University Press, Buckingham

Taggart P (2004) Populism and representative politics in contemporary Europe. J Political Ideol 9(3):269-288

Tarchi M (2008) Italy: A country of many populisms. In: Albertazzi D, Duncan M (eds) Twenty-first century populism. The spectre of western European democracy. Palgrave Macmillan, New York, NY, pp 84-99

Tarchi M (2015a) Italia populista. Dal qualunquismo a Beppe Grillo. il Mulino, Bologna

Tarchi M (2015b) Italy: the promised land of populism? Contemp Ital Polit 7 (3):273-285

van Kessel S, Castelein R (2016) Shifting the blame. Populist politicians' use of Twitter as a tool of opposition'. J Contemp Eur Res 12(2):594-614

Wirth W, Esser F, Wettstein M, et al. (2016) The appeal of populist ideas, strategie and styles: A theoretical model and research design for analyzing populist political communication. Working paper no.: 88. Available from: http://www. nccr-democracy.uzh.ch/publications/workingpaper/pdf/wp88.pdf

\section{Data availability}

Some of the datasets generated during the current study are available in the form of tables. Facebook datasets analysed during the current study are not publicly available because they form part of the authors' on-going research. They are available from the corresponding author on reasonable request.

\section{Additional information}

Competing interests: The authors declare no competing interests.

Reprints and permission information is available online at http://www.nature.com/ reprints

Publisher's note: Springer Nature remains neutral with regard to jurisdictional claims in published maps and institutional affiliations.

cc) (i) Open Access This article is licensed under a Creative Commons Attribution 4.0 International License, which permits use, sharing, adaptation, distribution and reproduction in any medium or format, as long as you give appropriate credit to the original author(s) and the source, provide a link to the Creative Commons license, and indicate if changes were made. The images or other third party material in this article are included in the article's Creative Commons license, unless indicated otherwise in a credit line to the material. If material is not included in the article's Creative Commons license and your intended use is not permitted by statutory regulation or exceeds the permitted use, you will need to obtain permission directly from the copyright holder. To view a copy of this license, visit http://creativecommons.org/ licenses/by/4.0/.

(C) The Author(s) 2018 